\title{
Theoretical grounds of labour demotivation diagnostics in the light of eighth SDG ${ }^{1}$
}

\author{
Bobdan-Petro Koshoryi , Ilona Petryk $k^{* *}$, Andrii Yevstakherych ${ }^{* * *}$, Ira Von-Nagy ${ }^{* * * *}$
}

Received: 2021-05-05

Accepted: 2021-08-15

DOI: http:/ / doi.org/10.46489/lbsh.2021-1-2-4

\begin{abstract}
The eighth SDG concerns decent working conditions. A crucial role in supporting this SDG has a sustainable business. In this article, we have considered labour demotivation in the light of the eighth SDG. We stressed the importance of improving the diagnostics system of demotivation of labour for companies that want to increase profits and be socially responsible. During the literature review, we found a lack of research on labour demotivation and diagnostics. Therefore, we analysed the diagnostic systems' composition and substantiated the main stages, criteria, and functions of the diagnostic system of labour demotivation. We also discussed the prospects of integrating demotivation diagnostics into the enterprise management system. The results of this study can be the basis for further empirical analysis of labour demotivation and can be helpful for internal HR policies improvement.
\end{abstract}

Keywords: sustainable development goals, eighth SDG, labour demotivation, HRM

\footnotetext{
${ }^{1}$ To prevent conflict of interest, the Chairman of the Editorial Board managed the entire editorial process for this article according to the ethical standards of Law, Business and Sustainability Herald (bttp:/ / lbsherald.org/index.php/journal/ ethicalst)

* Bohdan-Petro Koshovyi, PhD, Head of the Department of Demography, Labor Relations and Social Policy, Lviv University of Business and Law, Kulparkivska str., 99, 79021 Lviv, Ukraine, e-mail: qqbkqq@gmail.com (corresponding author), ORCID: https://orcid.org/0000-0001-8550-0028

** Ilona Petryk, DSc, Associate Professor, adiunkt, Faculty of Finance and Information Technology, University of Finance and Law, Czesława Tańskiego 5, 43-382 Bielsko-Biała, Poland, ORCID: https://orcid.org/0000-0002-2171-8180

*** Andrii Yevstakhevych, PhD, lecturer, Department of Business Economics and Information Technology, Lviv university of business and law, Kulparkivska, 99, 79021 Lviv, Ukraine, ORCID: https://orcid.org/0000-0003-1058-5359

**** Ira Von- Nagy, Dr. med., Fachärztin für HNO-Heilkunde, Chiemgauerstraße 144, 81549 München, Germany, ORCID: https://orcid.org/0000-0002-2748-7766
} 


\section{INTRODUCTION}

Modern enterprises value their authority and worry about the impact they have on the environment. However, within the company can mature processes that will negatively affect the brand and market position. One of the threatening phenomena may be the demotivation of labour. The eighth goal of sustainable development (SDG) is to ensure sustainability. We seek to explore at a theoretical level the content, features and possibilities of identifying work motivation in a particular enterprise.

This study is important given the international importance of work and the related problems arising from work's social and psychological nature.

The main stages of development of the labour demotivatiot concept correlate with the progress of the motivation of human labour activity. The science of motivation in its development has gone through several stages (Tripathi, N., \& Ghosh, V., 2017). In ancient times the motivation was performed mainly through violent rather than rewarding methods. Currently, motivation gets diverse forms, depending on owners and managers' knowledge and wishes.

A sustainable enterprise cannot function in current economic conditions without proper theoretical and methodological support for the construction of mechanisms for motivating employees (Bajo Sanjuán, A., González Álvarez, M., \& Fernández Fernández, J. L., 2013). Human labour and labour motivation are the drivers of economic progress, the prosperity of the individual enterprise, and the economy. This recognized thesis has recently lost its weight due to macroeconomic instability, the complication of the financial condition of many enterprises due to the prolonged economic recession, which usually leads to a weakening of attention to the human factor (Tomlinson, J., 2011).

F. Herzberg, a scientist whose name is associated with the emergence of the doctrine of demotivation, noted the expected results of economic and social research using his theory (Herzberg, F., Mausner, B., \& Snyderman, B. B., 2017). He drew attention to a study by $\mathrm{R}$. Praxam, conducted in 1982 based on textile enterprises in Bombay. Research has shown that employees receive too little satisfaction from the content of work. Shortly after the study was completed, textile workers went on strike, and after a 21-month downtime, the state had to transfer the plants to state ownership. F. Herzberg noted that when an employee seeks pleasure solely in hygiene, he begins to strike or abandon motivators and leans towards hygienic factors. This thesis emphasizes the importance of an in-depth study of labour demotivation as a threat to enterprise security and sustainable development.

\subsection{Literature overview}

The problem of labour demotivation today remains poorly understood. Among the prominent scholars of the past, F. Herzberg addressed demotivation directly (except for this term). In almost every scientific work devoted to staff motivation, there is a mention of the two-factor theory substantiated by F. Herzberg. The popularisation of F. Herzberg's theory was facilitated by his position on a two-stage algorithm for forming an effective employee motivation system. First, it is necessary to eliminate demotivating factors and introduce or strengthen motivation (Juariyah, L., \& Saktian, I. R., 2018). Nevertheless, despite considerable attention to his "two-factor theory of motivation", the problem of demotivation of labour is practically unexplored in current economic conditions.

Svietlov, BT, \& Boldyriev, OP (2011), analysing innovative approaches to the formation of competitive labour market infrastructure, emphasise the need to consider the demotivation of labour as one of the critical issues.

At the present stage, scientists focus on solving such scientific problems as the essence of labour demotivation, staff demotivation and demotivators (Pera, R., Menozzi, A., Abrate, G., \& Baima, G., 2021; Bukhari, H., Thaheem, MJ, Musarat, MA, Alaloul, WS, \& Altaf, M., 2021; Yadav, M., \& BaniAta, H., 2013). In addition, demotivation can be a specific state of personality that forces a person to misbehave under certain conditions (Ohlig, J. et al., 2021), thus distorting traditional behavioural patterns).

Very few researchers have directly considered demotivation. Bohdan, N.N. \& 
Mohylevkyn, E.A. (2004) formulated the author's understanding of the essence of demotivation. They identified the stages and the main detrimental consequences for the company due to the growth of demotivation processes. Dulzon AA (2010) considered demotivation in parallel with the need to ensure quality change management. He believed that mistakes in the implementation of organisational change lead to increased motivation. However, the term "demotivation" is used as the antithesis of motivation. Gligor, D. M., Pillai, K. G., \& Golgeci, I. (2021) noted the urgency of increasing attention to motivation in today's globalisation and business informatisation.

In motivational management, the problem of demotivation processes is considered Nazaryshyn, R.O. (2003). He researched the motivation and demotivation of industrial personnel, substantiated the need to overcome demotivation processes to motivate the quality of work, and the feasibility of "antidemotivation management" as a new management direction. For example, Riznyk, V. V. (2010) noted that if motivation is a process of inner awakening of a person to achieve goals, then demotivation can be described as a process resulting from a person's inner desire to act decreases. Diefenbach, S., \& Müssig, A. (2019) described the shortcomings of control systems that lead to demotivation at the application level. Oyedele, L.O. (2013) described the process of demotivation at the organisational level and at the level of the HRM system research provided by García-Campayo, J., Puebla-Guedea, M., Herrera-Mercadal, P., \& Daudén, E. (2016) and Carroll, V.P., Lee, H.L., \& Rao, A.G. (1986). On the example of medical organisations, demotivation was studied by Szabo, S. et al. (2020). For group work, the problem of demotivation was considered by Eddy-U, M. (2015). Yadav, M., \& BaniAta, H. (2013) described some demotivation factors. Factor analysis of certain aspects of demotivation was performed by Munir, R. I. S., \& Rahman, R. A. (2016). Green-Demers, I., Bouchard, S., Forest, G., \& Yelle, M. (2008) studied psychological aspects of demotivation. The connection between demotivation and sustainable development of the organization was revealed by Gab Allah, A. R., Elshrief, H. A., \& Ageiz, M. H. (2020)
Researchers rarely consider demotivation as a threat to sustainable entrepreneurship. Therefore, it is likely that management staff will ignore the need to overcome the demotivation of work due to poor financial security or lack of appropriate qualifications (Kuruba, M., 2019). In conditions of limited scientific support, the problem of labour demotivation can be perceived by managers as an inconvenience that can be tolerated while funding is limited.

The lack of a systematic approach to the evaluation of demotivators is noticeable in scientific sources. We note the methodological inaccuracy in quoting several demotivators. Thus, leadership style, ignoring ideas and initiatives are demotivators characteristic of management and those manifested in external human behaviour, and therefore have a demotivating value (Weinberger, L. A., 2009). Lack of a sense of belonging to the company, a sense of personal and professional growth (Ghosh, S., 2010) are already internal demotivators of the employee, lack of resources - an external objective demotivator of the environment.

In our opinion, the lack of a classification of demotivating factors in combination with the lack of appropriate caution can lead to ignoring other important demotivators in the process of practice management. In the case when the manager does not know the categories (such as external or internal demotivators or long-term or short-term demotivators, et cetera), but specific examples of demotivation in the company over time may be a situation where known demotivators have been eliminated, and productivity does not increase due to the active action of unknown to the head demotivators (Wilkinson, A., Redman, T., \& Snape, E., 1994).

Demotivation has a subjective nature and occurs under the influence of external and internal factors and negatively affects the desire, willingness, and ability of the employee to perform their duties and tasks and achieve organizational goals. Demotivation influences their acceptance decisions regarding one's position in the workforce, organization, change of place of work, committing illegal actions towards the organization or colleagues, provoking or participating in conflicts and other issues related to work (Gundry, L.K., Kickul, J.R., \& Prather, C.W., 1994). 
So, we asked the following research questions:

$\mathrm{RQ}_{1}$ : What is the content of the system of diagnostic demotivation of labour?

$\mathrm{RQ}_{2}$ : What are the main stages of diagnosis of labour demotivation?

$\mathrm{RQ}_{3}$ : What criteria and functions of the system of diagnostics of demotivation of work are essential?

\section{METHODS}

This article presents the results of theoretical research. We relied on the theory of motivation and took into account the general principles of personnel management and our own experience in this area. The source base was research on motivation and demotivation of work. This study has the following structure. First, we briefly described the importance of diagnostic systems for the enterprise. Then we revealed the stages of diagnosis of labour demotivation, which can become the system's backbone. We also described the criteria and functions of the system of diagnostic demotivation of labour, which will facilitate its faster implementation in the work of enterprises. Finally, we discussed the prospects of integrating demotivation diagnostics into the enterprise personnel management system for sustainable development.

\section{RESULTS}

\section{1. The content of the system of} diagnostics of labour demotivation

Subjective features of personnel management in the context of enterprise management are the subject of many scientific discussions. However, to date, the transition from the objective plane of the controlled environment of entrepreneurial activity to the subjective dimension of labour relations is often accompanied by unjustified generalizations or excessive attention to some factors of labour behaviour to the detriment of others. At the same time, the study of labour demotivation as a threat to the enterprise's sustainable development cannot cover several subjective factors. After all, any objective actions of management can damage the motivation system and cause demotivation of work not because of their imperfections or lack of experience, skills, abilities of managers but in connection with how employees will react to these actions (Berger, I.E., \& Mitchell, A.A., 1989).

Depending on the strategic guidelines of the enterprise, different models can be used. However, to substantiate the basics of forming a system for labour demotivation diagnostics, we should consider the existing scientific approaches to interpreting HR diagnostics. Thus, based on the study of Artiukh-Pasiuta, O. V. (2013), diagnosis is the process of studying the system's current state, establishing causal relationships between its elements, analysing and evaluating the system according to specific criteria, and identifying prospects for its development.

Diagnosis of the threat of demotivation of labour on explicit grounds is similar to the diagnosis of a crisis (Batorski, J., 2011). In our opinion, the purpose of the system of diagnostics of labour demotivation is to monitor demotivation processes and phenomena and manage them to prevent the growing threat to the economic security of the enterprise.

\section{2. Stages of diagnostics of labour demotivation}

In the following, we will combine theoretical considerations into several essential stages in diagnosing labour demotivation.

I. Analysis of external and internal factors that provoke the emergence of demotivation of labour (Michaelson, C., 2005). At this stage in the arsenal of the researcher or manager should be the latest theoretical and methodological developments of both general diagnostic nature and information about the features of a particular system (enterprise) and its subsystems, which will adapt methods of collecting and analysing information to specific needs and resource potential of the enterprise (including financial and labour).

Analysing demotivation factors requires proper objectivity (Makridakis, S., Assimakopoulos, V., \& Spiliotis, E., 2018). Obstacles of a subjective nature can question the reliability of the source information, which will affect the effectiveness of activities to overcome the demotivation of labour. Recognition of existing problems both at the macro level and in the internal environment is 
often opposed by those who may have underestimated the phenomena of the objective world, which pose a real threat and cause labour demotivation. Overcoming this should be purposeful work both to build an independent system of analysis of objective phenomena and to overcome employees' resistance, in particular by changing the organisational culture in the direction of recognition and intensified work on their own mistakes.

At this stage, the information-analytical nature of the activity (Selart, M., Tvedt Johansen, S., Holmesland, T., \& Grønhaug, K., 2008) necessitates the development of additional tools and its implementation, as well as the improvement of knowledge and skills. The analysis of the factors of the labour demotivation should include the elements of other information technologies to simplify management activities and improve its efficiency, which will not require significant additional resources.

Labour discipline is also essential (Liestiani, NL, Perizade, B., Hanafi, A., \& Zunaidah, Z., 2019), namely the ability of responsible employees to analyse on time and in whole, not to ignore difficulties, to look for new ways to improve methods of analysis and presentation of the received information.

II. At the stage of identifying shortcomings and problems, there is an initial reassessment of ideas about the state of labour demotivation considering the data obtained at the first stage and preliminary information about the state of the enterprise. Of particular importance at this stage is the correct construction of the system of evaluation criteria, which will eliminate the subjective component and generally positively affect the entire diagnostic system.

Moreover, organisational culture becomes especially important (Martinez, E. A. et al., 2015). An objective attitude to the identified shortcomings is possible provided that all employees, without exception, treat their work responsibilities responsibly.

Elimination of shortcomings is a consequence of the purposeful improvement of the personnel management system of the enterprise in order to improve management, improve the socio-psychological, motivational climate, minimise inefficient use of time and resources of the organisation. Instead, problems often occur during the operational management of the enterprise and require tactical measures, making specific management decisions in a limited time (Khodadadi, A., Fakhari, P., \& Busemeyer, J. R., 2017).

To identify shortcomings leading to labour demotivation, managers should compare the HR management system of the analysed enterprise and the industry leader. Detection of shortcomings that provoke the demotivation of work can be done based on cognitive maps, SWOT analysis, brainstorming, et cetera.

To identify problems inside the HR management, formal and informal indicators could be helpful. Formal indicators include those obtained by analysing the results of the enterprise, holding meetings, conferences, processing complaints and suggestions, analysing feedback on the enterprise. Informal can be assessed in personal communication with employees and consumers. So, the responsible employee should be hired depending on their communication skills.

III. At the stage of developing proposals to address the problems and shortcomings associated with the demotivation of labour again comes in handy the latest methodological apparatus, which should accurately assess the costs necessary to normalise the situation (eliminate or reduce demotivation) and their effectiveness (Conciarelli, A., 2014).

Appropriate proposals can be multifaceted and largely depend on such related factors as corporate culture, personnel policy, management styles traditionally adopted in the enterprise, and others. These factors must be taken into account because the best of the proposals may break down into inconsistency with traditional management ideas about approaches to solving the problem of work demotivation, based on deep experience and knowledge of all the intricacies of enterprise management (Rotemberg, J. J., \& Saloner, G., 1993).

The best way of proposal making is to conduct a collective discussion of existing problems. Differences in worldviews and qualifications of different employees can be helpful to resolve issues that are beyond the competence of the manager who makes the final decision. However, building an effective 
system of collective nomination and discussion of proposals is not an easy task and can be implemented only in the context of a democratic organisational culture.

The lack of communication channels at this stage threatens to increase the threat of demotivation of labour. Elimination of the proposals of ordinary employees, who often suffer the most from the demotivation of work, will not bring the expected result (Schwenk, C. R., 1995). Regarding organisational communications, there is a large amount of research in modern science.

At this stage, it is imperative to monitor the work of external consultants, if any, as their findings may often be inconsistent with the actual state of affairs in the company, which can lead to misinterpretation of ways, methods and means to reduce the threat of demotivation.

IV. The stage of making and implementing a management decision to solve the labour demotivation should be performed in close cooperation of all parties to the process (Owen, D., 2015). Although the diagnostic system is primarily a tool for providing the latest reliable information, it is the decision-making process that translates its functioning from the theoretical-informational to the praxeological plane, involving all employees in discussions of possible decisions. This approach is possible with the consistent democratisation of the process. Furthermore, this approach will avoid an essential obstacle in overcoming the demotivation of labour - the lack of communicative support for decision-making and implementation.

At the same time, the democratisation of the decision-making process on specific aspects of the threat of demotivation of labour and its overcoming should not mean collective responsibility. However, the implementation of the individual decision of the head is greatly simplified if it is agreed and supported by the majority of staff and consumers of educational services (Simon, H. A., et al. 1987).

Inseparable from the decision-making process is the process of their implementation, which is why we considered it appropriate to combine these two processes into a single stage. The transition from theorising to the practical implementation of measures to overcome the demotivation of labour is a prerequisite for strengthening the economic security of the enterprise (higher education institution) in the field of personnel management.

The stage of decision-making and implementation does not finalise the diagnostics but leads to a new round. Indeed, a diagnostic system that does not function continuously and cyclically cannot be considered suitable for solving highly complex problems that arise in the field of labour demotivation as a threat to the economic security of the enterprise.

\section{3. Criteria and functions of the labour demotivation diagnostics}

The system of diagnostics of labour demotivation as a threat to sustainable development should consider several diagnostic criteria. Such criteria we propose to include:

- the company's attitude to the risk group in the field of personnel safety;

- the level of economic security of the enterprise; indicator;

- the value of the personnel safety

- actual resources for threat prevention;

- rescue reserves in case of threat;

- the level of attracting additional resources to overcome the threat;

- the effectiveness of rescue management.

The diagnostic system should perform several functions (Turner, J. R., 2006). We distinguish the most critical functions: informational, analytical, guiding, identification, warning, regulatory, consulting. Of these functions, when it comes to the threat of demotivation of labour, the most important seems to be a warning.

The priority of the preventive function follows from the purposeful nature of the system for diagnosing the threat of labour demotivation. Ensuring the proper performance of the warning function by the diagnostic system cannot occur without the implementation of other functions. Thus, the information function allows the person responsible for decision-making on a particular path of development of processes that can be reborn in demotivation to receive information 
about the current state of affairs in the enterprise and quickly navigate in a changing environment.

The role of the information function in preventing the threat of demotivation of labour is prominent. Without accurate information about the current state of affairs, it is difficult to objectively assess the existing risks and take the necessary measures to prevent the threat. Therefore, the information function is supplemented by analytical. Such an addition is especially relevant when a large amount of information needs to be appropriately evaluated to make the necessary decision. The analytical function in the diagnostic system can be formally assigned or performed directly by the person who makes decisions based on the obtained data.

With the growing number of employees, the complexity of technical and technological production processes, the formal consolidation of the analytical function, taking into account the universal method of information analysis is inevitable because spontaneity, subjectivity in the analysis of diagnostic information can lead to different decisions and disharmony in the operation of individual departments. However, in the process of such transformations, we should not forget about the consistency and harmony of the diagnostic system.

Within the analytical function of particular importance is a well-formed arsenal of indicators and indicators, which are used to assess the information coming into the diagnostic system. The indicators and indicators of the diagnostic system are connected with its function as identification.

The identification function of the diagnostic system can apply in general to all threats when it comes to the sustainable development of the enterprise. In fact, in the process of implementing this function, individual threats and probabilities are identified, as well as the severity of the consequences and the cost of overcoming their occurrence. A diagnostic system that deals with only one significant threat should provide a clear answer to whether the events fall under the general picture of the demotivation process.

Given the above and monitoring the practice of managing a private higher education institution, we note that the construction of a quality system for diagnosing demotivation of labour and its effective functioning largely depends on the effectiveness of the personnel management system in general. Thus, diagnostic systems created for purposes other than detecting the threat of work demotivation (diagnostics of quality, staff efficiency, performance indicators, et cetera) simplifies the task of building an effective system for diagnosing work demotivation. At the same time, the diagnosis of demotivation can not arise by itself in isolation from the strategy of personnel management in the enterprise. In ensuring the overcoming of the threat of demotivation of labour, it is expedient to profess not a revolutionary but an evolutionary path. Staffing the process is also essential.

Given the ultimate goal of business management with a view to sustainable development, a diagnostic system that protects against the threat of demotivation of labour must be integrated into other subsystems of enterprise management.

\section{DISCUSSION}

We consider prospects for further integration of the demotivation diagnostics through a generalized perception of the enterprise's sustainable development strategy. In the context of overcoming a wide range of threats that arise in doing business, ignoring the demotivation of labour is unacceptable. At the same time, the system of diagnosing the threat of labour demotivation may be suitable for diagnosing related threats (related to labour regulation, labour discipline, social and labour relations). Furthermore, as it develops, this system will become suitable for diagnosing threats related to personnel management and other spheres of enterprise management (finance, marketing, production, technical and technological spheres, et cetera).

In addition to "geographical" integration (with other diagnostic systems), improving the diagnosis of demotivation of labour involves strengthening the identification of the objective patterns of deterioration of economic security of the enterprise in connection with demotivation and subjective. In the unity of the objective conditions of management and the subjective world of the employee, it is possible to achieve much better results in overcoming the threat of demotivation of labour. 
Thus, in the end, the system of diagnosing labour demotivation in its implementation can provide solutions not only to current problems of reducing the quality of education due to the threat but also to provide a systemic effect, which is another argument in favour of its implementation in enterprise management.

\section{Limitations}

This research is theoretical and aims at popularizing the research in the field of labour demotivation. Therefore, the implementation of these recommendations should be carried out after their empirical verification.

\section{CONCLUSIONS}

In this study we proved that the system of diagnosis of the threat of labour demotivation should focuse on the assessment of objective processes and phenomena of the real world and the subjective world of the employee. Thus, this study demonstrates the existence and relevance of two approaches to overcoming labour demotivation as a threat to the economic security of the enterprise on the path of sustainable development. The first approach is subjective and is based on assumptions about

\section{References}

Artiukh-Pasiuta, O. V. (2013). Diahnostyka systemy upravlinnia personalom pidpryiemstva. Naukovyi visnyk Poltavskoho universytetu ekonomiky i torhivli. Ser.: Ekonomichni nauky, 2, 158-162. http://nbuv.gov.ua/jpdf/Nvpusk_2013_2_27.pdf.

Bajo Sanjuán, A., González Álvarez, M., \& Fernández Fernández, J. L. (2013). Responsabilidad social y empresa sostenible. AdComunica: Revista Cientifica de Estrategias, Tendencias e Innovación En Comunicación, 2013(5), 223-243. https://doi.org/10.6035/2174$\underline{0992.2013 .5 .14}$

Batorski, J. (2011). Fragmentation of crisis management in an enterprise. Serbian Journal of Management, 6(2), 283-286. https://doi.org/10.5937/sjm1102283B

Berger, I. E., \& Mitchell, A. A. (1989). The Effect of Advertising on Attitude Accessibility, Attitude Confidence, and the Attitude-Behavior Relationship. Journal of Consumer Research, 16(3), 269. https://doi.org/10.1086/209213 the dynamics of the internal structure of employee motives, changes in their weight following changes in environmental conditions and the decisive influence of internal motives on employee behaviour and thus - the quality of work that determines the eighth goal of sustainable development. The second approach is objective and is based on causal links between external influences on employee behaviour and changes in this behaviour. It does not exclude internal motives but primarily considers their manifestation in the employee's actual behaviour. Comparing the obtained results with the existing developments in enterprise management, personnel, labour, we conclude that these two approaches are entirely consistent with current trends in attempts to explain the labour behaviour of employees and the peculiarities of its change and impact on it by managers.

The results of this study may be the basis for further empirical research on labour demotivation and valuable for the development of internal policies for enterprise development to achieve the eighth goal of sustainable development.

Bohdan, N.N. \& Mohylevkyn E.A. (2004). Motyvatsyia y demotyvatsyia professyonalnoi deiatelnosty personala VUZa (na prymere vuzov Dalnevostochnoho federalnoho okruha). Unyversytetskoe upravlenye: praktyka y analyz, 3, 8997.

Bukhari, H., Thaheem, M. J., Musarat, M. A., Alaloul, W. S., \& Altaf, M. (2021). Are Pakistani construction professionals truly happy? A benchmarking approach. Ain Shams Engineering Journal, S209044792100188X. https://doi.org/10.1016/j.asej.2021.04.012

Carroll, V. P., Lee, H. L., \& Rao, A. G. (1986). Implications of Salesforce Productivity Heterogeneity and Demotivation: A Navy Recruiter Case Study. Management Science, 32(11), 1371-1388.

https://doi.org/10.1287/mnsc.32.11.1371

Conciarelli, A. (2014). A new macroprudential tool to assess sources of financial risks: implied-systemic cost of risks: Iscor: a new framework to assess financial risks. International Journal of Finance \& Economics, 19(1), 74-88. https://doi.org/10.1002/ijfe.1478 
Diefenbach, S., \& Müssig, A. (2019). Counterproductive effects of gamification: An analysis on the example of the gamified task manager Habitica. International Journal of Human-Computer Studies, 127, 190-210. https://doi.org/10.1016/j.ijhcs.2018.09.004

Dulzon, A.A. (2010). Menedzhment yzmenenyi y demotyvatsyia personala VUZa. Problemы upravlenyia v sotsyalnokh systemakh, 2(3), 78-92.

Eddy-U, M. (2015). Motivation for participation or non-participation in group tasks: A dynamic systems model of tasksituated willingness to communicate. System, 50, 43-55.

https://doi.org/10.1016/j.system.2015.03.005

Gab Allah, A. R., Elshrief, H. A., \& Ageiz, M. H. (2020). Developing Strategy: A Guide For Nurse Managers to Manage Nursing Staff's Work-related Problems. Asian Nursing Research, 14(3), 178-187. https://doi.org/10.1016/j.anr.2020.07.004

García-Campayo, J., Puebla-Guedea, M., Herrera-Mercadal, P., \& Daudén, E. (2016). Burnout Syndrome and Demotivation Among Health Care Personnel. Managing Stressful Situations: The Importance of Teamwork. Actas Dermo-Sifiliográficas (English Edition), 107(5), 400406.

https://doi.org/10.1016/j.adengl.2016.03.003

Ghosh, S. (2010). Affiliation and firm performance: evidence from Indian business groups. The Manchester School, 78(3), 183-200. https://doi.org/10.1111/j.1467-

9957.2009.02142.x

Gligor, D. M., Pillai, K. G., \& Golgeci, I. (2021). Theorizing the dark side of business-tobusiness relationships in the era of AI, big data, and blockchain. Journal of Business Research, 133, 79-88.

https://doi.org/10.1016/j.jbusres.2021.04.043

Green-Demers, I., Bouchard, S., Forest, G., \& Yelle, M. (2008). L'impact de la démotivation scolaire et de la dévalorisation personnelle sur la dépression et l'anxiété à l'adolescence. Journal de Thérapie Comportementale et Cognitive, 18, 9. https://doi.org/10.1016/S11551704(08)74804-3

Gundry, L. K., Kickul, J. R., \& Prather, C. W. (1994). Building the creative organization.
Organizational Dynamics, 22(4), 22-37. https://doi.org/10.1016/0090-2616(94)90076$\underline{0}$

Herzberg, F., Mausner, B., \& Snyderman, B. B. (2017). The Motivation to Work (1st ed.). Routledge.

https://doi.org/10.4324/9781315124827

Juariyah, L., \& Saktian, I. R. (2018). Does

Motivators Determine Employees' Job Satisfaction? Testing Herzberg Theory of Motivation in Indonesian Café and Restaurant Context. KnE Social Sciences, 3(3), 482. https://doi.org/10.18502/kss.v3i3.1905

Khodadadi, A., Fakhari, P., \& Busemeyer, J. R. (2017). Learning to allocate limited time to decisions with different expected outcomes. Cognitive Psychology, 95, 17-49. https://doi.org/10.1016/j.cogpsych.2017.03.00 $\underline{2}$

Kuruba, M. (2019). Competency Management. In M. Kuruba, Role Competency Matrix (pp. 17-26). Springer Singapore. https://doi.org/10.1007/978-981-13-7972-7_3

Liestiani, N. L., Perizade, B., Hanafi, A., \& Zunaidah, Z. (2019). The Effect of Work Discipline and Work Environment on the Performance of AL Hudori Cooperative of Palembang Employees. Journal of Economics and Business, https://doi.org/10.31014/aior.1992.02.01.67

Makridakis, S., Assimakopoulos, V., \& Spiliotis, E. (2018). Objectivity, reproducibility and replicability in forecasting research. International Journal of Forecasting, 34(4), 835-838.

https://doi.org/10.1016/j.ijforecast.2018.05.00 $\underline{1}$

Martinez, E. A., Beaulieu, N., Gibbons, R., Pronovost, P., \& Wang, T. (2015). Organizational Culture and Performance. American Economic Review, 105(5), 331-335. https://doi.org/10.1257/aer.p20151001

Michaelson, C. (2005). Meaningful Motivation for Work Motivation Theory. Academy of Management Review, 30(2), 235238.

https://doi.org/10.5465/amr.2005.16387881

Munir, R. I. S., \& Rahman, R. A. (2016). Determining Dimensions of Job Satisfaction Using Factor Analysis. Procedia Economics and Finance, $\quad 37, \quad$ 488-496. 
https://doi.org/10.1016/S2212-

5671(16)30156-3

Nazaryshyn, R.O. (2003). Zabezpechennia motyvatsii yakosti pratsi shliakhom podolannia demotyvatsiinykh protsesiv. Visnyk Volynskoho instytutu ekonomiky ta menedzhmentu, 6, $91-99$.

Ohlig, J., Hellebrandt, T., Poetters, P., Heine, I., Schmitt, R. H., \& Leyendecker, B. (2021). Human-centered performance management in manual assembly. Procedia CIRP, 97 , 418-422.

https://doi.org/10.1016/j.procir.2020.05.261

Owen, D. (2015). Collaborative Decision Making. Decision Analysis, 12(1), 29-45. https://doi.org/10.1287/deca.2014.0307

Oyedele, L. O. (2013). Analysis of architects' demotivating factors in design firms. International Journal of Project Management, 31(3), 342-354.

https://doi.org/10.1016/j.ijproman.2012.11.00 $\underline{9}$

Pera, R., Menozzi, A., Abrate, G., \& Baima, G. (2021). When cocreation turns into codestruction. Journal of Business Research, 128, 222-232.

https://doi.org/10.1016/i.jbusres.2021.01.058

Riznyk, V. V. (2010). Suchasni tendentsii motyvatsii pratsi upravlinskoho personalu. Ekonomichnyi visnyk universytetu, 15/1, http://archive.nbuv.gov.ua/portal/soc_gum/ev u/2010_15_1/RiznikV.pdf.

Rotemberg, J. J., \& Saloner, G. (1993). Leadership Style and Incentives. Management Science, 39(11), 1299-1318. https://doi.org/10.1287/mnsc.39.11.1299

Schwenk, C. R. (1995). Strategic Decision Making. Journal of Management, 21(3), 471-493. https://doi.org/10.1177/014920639502100304

Selart, M., Tvedt Johansen, S., Holmesland, T., \& Grønhaug, K. (2008). Can intuitive and analytical decision styles explain managers' evaluation of information technology? Management Decision, 46(9), 1326-1341. https://doi.org/10.1108/00251740810911975

Simon, H. A., Dantzig, G. B., Hogarth, R., Plott, C. R., Raiffa, H., Schelling, T. C., Shepsle, K. A., Thaler, R., Tversky, A., \& Winter, S. (1987). Decision Making and Problem Solving.
Interfaces, $\quad$ 17(5), 11-31.

https://doi.org/10.1287/inte.17.5.11

Svietlov, B.T., \& Boldyriev, O.P. (2011). Rynok pratsi Ukrainy $\mathrm{V}$ aspekti innovatsiinoho formuvannia yoho konkurentospromozhnoi struktury. Teorii mikro-makroekonomiky, 36, http://archive.nbuv.gov.ua/portal/soc_gum/T $\underline{\mathrm{mm} / 2011 \text { 36/16.pdf }}$

Szabo, S., Mihalčová, B., Lukáč, J., Gallo, P., Čabinová, V., \& Vajdová, I. (2020). Demotivation of Medical Staff in the Selected Health Facility in Slovakia. E+M Ekonomie a Management, 23(2), 83-95. https://doi.org/10.15240/tul/001/2020-2-006

Tomlinson, J. (2011). Out of Recession? New Political Economy, 16(5), 655-665. https://doi.org/10.1080/13563467.2011.60181 $\underline{0}$

Tripathi, N., \& Ghosh, V. (2017). Work Motivation: History, Theory, Research, and Practice by Gary P. Latham: 2nd Edition, Sage Publications, Inc., Thousand Oaks, CA, 2012, xxix + 424 pp, $\$ 77$ (Paperback), ISBN: 978-14129-9093-6. Psychological Studies, 62(1), 109111. https://doi.org/10.1007/s12646-017$\underline{0388-8}$

Turner, J. R. (2006). Towards a theory of project management: The nature of the functions of project management. International Journal of Project Management, 24(4), 277-279. https://doi.org/10.1016/j.ijproman.2006.03.00 $\underline{2}$

Weinberger, L. A. (2009). Emotional Intelligence, Leadership Style, and Perceived Leadership Effectiveness. Advances in Developing Human Resources, 11(6), 747-772. https://doi.org/10.1177/1523422309360811

Wilkinson, A., Redman, T., \& Snape, E. (1994). Quality Management and the Manager: A Research Note on Findings from an Institute of Management Study. Employee Relations, 16(1), 62-70.

https://doi.org/10.1108/01425459410054934

Yadav, M., \& BaniAta, H. (2013). Factorizing Demotivation, Finding Motivation: A Constructive Approach to Quality Enhancement. Procedia - Social and Behavioral Sciences, $\quad 70, \quad 120-130$. https://doi.org/10.1016/j.sbspro.2013.01.047 